\title{
Disease-of-the-month alive and well
}

\section{Identifying diseases in need of a cure is easy and the temptation to follow that with money appears to be irresistible, but it has not always proved to be successful. Research money should follow scientific opportunity.}

IN the United States and several European nations, this is the "Decade of the brain". In the United States it is also a decade recently dedicated to "Women's health". Since the National Cancer Act of 1971, when the White House declared a fullblown "war on cancer", the US National Institutes of Health (NIH) has been gamely searching for strategies to stop the unyielding progression of tumour cells from disease to death but all too often the tumours are still winning. So is the phenomenon we call ageing, despite the creation in 1976 of a National Institute on Aging whose scientists are tackling everything from the normal deficiencies that decades of wear and tear inflict on the body to the mental ravages of senility and Alzheimer's disease.

The desire to cure disease (and to prevent it in the first place) may be one of human beings' most basic instincts. It is laudable and not without success. Particularly in the developed nations of the world, where sanitation, vaccination and antibiotics, as well as modern surgery, are generally available, numerous diseases can be brought under control. And even for the more recalcitrant diseases, modern medicine can offer a greatly enhanced quality of life for longer periods of time than ever before. But the scientific search for understanding is far from complete (perhaps adolescent, at best).

In this environment, the increasingly crass politicization of biomedical research looms as something of a menace for it presupposes first that more money for more scientists is the way to medical salvation, and second that well-meaning groups of citizen-activists and professional lobbyists have a scientifically useful role in deciding where research money should be directed. There is, alas, inadequate evidence to support either proposition. Recent history illustrates a point that should have been learned long ago.

- Breast cancer. An influential group of activists organised as the Breast Cancer Coalition lobbied so successfully that Congress has allocated $\$ 210$ million of Department of Defense money for breast cancer research (see Nature 359, 764; 1992). Coming in addition to $\$ 197$ million for breast cancer already in the budget of the National Cancer Institute, the $\$ 407$ million total leaves basic researchers in the unenviable position of actually having more resources than can necessarily be well spent on basic science while other programs go NATURE · VOL 360 - 5 NOVEMBER 1992 wanting (see page 2). If the grand effort does not yield striking results, there may be political hell to pay. (Even the most zealous activists prepared a research agenda that would spend "only" $\$ 300$ million for breast cancer studies.)

Breast cancer and women's health. As this journal noted recently (see Nature $\mathbf{3 5 9}$, $760 ; 1992)$, under the mantle of its "Women's health initiative," the NIH plans to spend $\$ 10$ million on a large epidemiological study of the putative causal relation between breast cancer and dietary fat despite several good studies that have disappointingly shown no connection. But some women's groups appear to be unconvinced, and the faddish belief that all disease is directly related to diet seems to have overcome not only scientific data but common sense as well.

AIDS vaccine. In one of the more egregious examples of doing science by lobbying, a small biotechnology firm called MicroGeneSys in Meriden, Connecticut, managed to get Congress to pass legislation mandating that the Department of Defense allocate $\$ 20$ million for clinical trials of its AIDS vaccine (based on the gp 160 envelope of the human immunodeficiency virus), despite an absence of scientific consensus that this particular experimental vaccine is more promising than others. Bernadine Healy, director of the NIH, along with Food and Drug Administrator David Kessler, are now in the politically awkward position of trying to stop this lobbyist-driven clinical trial from proceeding. (They are right to do so.)

- AIDS drug. Valuable research dollars are about to be spent by NIH on studies of an interferon-based drug called Kemron that is popularly known as the "African AIDS cure" because of its association with studies in Kenya. Despite the fact that an NIH review panel has already investigated and rejected data purporting to show that Kemron is a significant AIDS remedy, racial politics demand yet another look and NIH likely will be hard pressed to resist (see Nature 359, 660; 1992).

These are but a handful of instances that demonstrate the power of politics over biomedical science. The history of NIH shows that, to some extent, it was ever thus. After the White House declared war on cancer in 1971, it elevated heart disease to special status (and funding) a year later. During the 1970 s the prevailing disease-of-the-month mentality that had every disease group touting its own cause led to the renaming of many of the NIH institutes, rendering their new identities not only unpronounceable but hard to remember as well. The National Heart Institute became the National Heart, Lung and Blood Institute. The arthritis lobby succeeded in getting Congress to establish a separate National Institute of Arthritis, but political pressures stretched it ever further to the National Institute of Arthritis and Musculoskeletal and Skin Diseases.

The bureaucracy has grown (it is estimated that it costs at least $\$ 5$ million a year in administrative costs alone to create new institutes) but, although some progress has been made, it is not yet possible to say that any of the diseases subject to special political attention has been cured as a result. The reason for this sad state is intellectually apparent even if politically unpopular, for the truth is that good science depends on good ideas (not good intentions) if it is to be successful. But even then the system does not always work ideally, as the "Decade of the brain" attests. If the impetus behind more research on breast cancer is a desire to stem the apparent rise in the disease, the push for more research in neuroscience is more clearly grounded in scientific opportunity.

During the past decade, important insights in the molecular analysis of cell lineage and neuronal migration make possible new studies of the central nervous system. The way the brain organizes the chemistry of the five senses is close to being understood. And some diseases may even be experimentally treatable with new techniques of gene therapy. But the "Decade of the brain" is little more than an empty declaration because it was not accompanied by the sums of money that Congress has earmarked elsewhere on a disease-by-disease basis.

It all comes down to the fact that in the United States, at least, the system for allocating research resources is badly in need of a complete overhaul. Even a doubling of the budget would not necessarily lead to money well spent unless there is a commitment to assigning research funds according to scientific opportunity. Although the NIH's much maligned "strategic plan" is meant to be a step in the direction of bringing scientific sense into a system run amok, it clearly does not go far enough when it comes to making tough but appropriate decisions.

Barbara J. Culliton 